\title{
ARCHITECTURE
}

\section{Functional-Spatial Features of The Architecture of The Scientocratic State on The Example of F. Bacon's Novel 'New Atlantis'}

\author{
A. Fedak \\ Lviv Polytechnic National University, Lviv, Ukraine \\ Corresponding author. E-mail: ann.fedak67@gmail.com
}

Paper received 05.02.20; Accepted for publication 21.02.20

https://doi.org/10.31174/SEND-NT2020-224VIII27-01

Abstract. The article is devoted to the analysis of the description and importance of architecture and functional-spatial planning in the utopian country in F. Bacon's novel 'New Atlantis'. The research presents the interdependence between functional content and the formation of utopia. The article summarizes the information on architecture and urban planning presented in the philosopher's novel, and also compares the description of architectural solutions with the works of the utopian philosophers T.More and T.Campanella.

Keywords: ideal city, utopia, public building, science.

Introduction. The concept of utopia occurs in the middle of the 16th century and is first used in the title of Thomas More's work 'Utopia'. Utopia is 'an imagined place or state of things in which everything is perfect' [1]. Among the first works that describe the utopian system are also the works of Plato (360-370-ies BC; 354 BC), Tommaso Campanella (1602), Johannes Valentinus Andreae (1619). A description of the author's vision of the ideal state, with appropriate social and political arrangements, is common to all these works.

'New Atlantis' by Francis Bacon is also referred to as a utopian work [2, c.191-224], and was published in 1624 for the first time. F. Bacon, being a philosopher, is the author of a large number of philosophical works and one of the founders of empiricism (knowledge based on experience). The development of science and the dissemination of knowledge are widely covered in his work.

A brief overview of the publications on the topic. The most common scientific works are aimed at the analysis of social and political structures, and at the importance of information and science in the formation of utopia in the works of Bacon: articles by O. Kartunov [3]; H. Yaldir, A. Dilmaçünal [4] etc.. Sandra Dragomir has compared the 'New Atlantis' by F. Bacon and the treatise 'Utopia' by T.More in her article. By comparison, the author demonstrates that "New Atlantis" has a significant number of differences from classic utopian work [5].

The aim of the article is to highlight and describe the importance of architecture and functional and spatial characteristics of the city and state described in F. Bacon's 'New Atlantis'.

Results and discussion. The events described by F. Bacon in 'New Atlantis' unfold on the island Bensalem, where the narrator, along with his crew, arrived as a result of a boat trip in the Pacific Ocean. The island state is located somewhere within the South Sea [2, c.193; 199] in the least explored part of the sea, away from all the surrounding continents [2, c.202]. There are at least 2 cities on the island (the city where the storyteller with his companions arrive, and the city of Renfusa [2, c.200]), though we assume from the text that there are more cities in fact [2, c.224]. The island itself is flat, mostly planted with trees [2, c.193]. The isolated location of the island resonates with the work of Thomas More since the island Utopia was also located in the middle of the ocean, separated from all the world (in the middle of nowhere).

Francis Bacon pays far less attention to the numerical characteristics of the state than his predecessors. Thus, we see exactly 5040 families in Plato's feudal city [6, c. 1926000 families in every city on the island Utopia described by T.More [7, c.62]. In the 'New Atlantis', the author only mentions the total length of the circle (the outline of the island), which is 5600 miles (approximately $3480 \mathrm{~km})$ [2, c.206].

The form of the government on the island Bensalem is a monarchy ruled by a king [2, c.212]. The church is of the same importance in the life of the country and the only religion followed by its inhabitants is Christianity.

Social equality is not so crucial for F. Bacon, thus, in contrast to works by previous utopian philosophers, it does not underlie a utopian system. The text mentions the different social status of the inhabitants that do not live on state donations contrary to works by T.More or Campanella. Although in case the family is tight on budget, the state offers financial help. If we talk about the household system of Bensalem, it is almost identical to the one in the UK at that time, except for much more active development of science. Thus, the main institution of the country is Solomon's House, which is a kind of embodiment of the Academy of Sciences [2, c. 49]. The Solomon House includes 36 people, where everyone performs a specific function such as travelling around the world, acting out as the inhabitants of other countries to keep the island in secret (12 persons); analyzing information from books (3 persons); studying mechanical sciences (3 persons) etc. [2, c.222-223]. Bacon's main idea is to form a society where knowledge and science, not social status or money, are the most important. For this purpose, the term scientocracy is developed, which means the formation of political and social relations of the state, namely based on science [8].

F. Bacon divides the entire area of the island into 3 different regions. The first is the Lower Region, located below the ground level. There are several artificially created mines on the island, the deepest of them reach six hundred fathoms. However, some mines go down the 
hills, thus reaching up to 3 miles deep. These mines are used to extract new resources and to study how subsurface influences human bodies that are cooled and stored there. The Upper Region boundary is determined by towers that extend up to half a mile in height. Besides, some towers are located on hills, so the total height is up to 3 miles. These towers serve as a platform for the study of celestial bodies, weather, and the like. Everything between the Upper and the Lower Regions is called the Middle Region, where the cities are located, and almost all human activity takes place (Fig. 1).

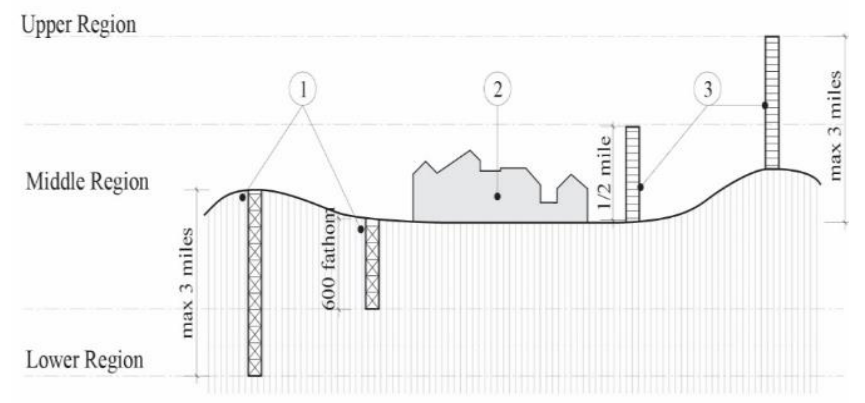

Fig. 1 - Three Regions, within which the inhabitants of Bensalem conduct scientific researches

1. Mines; 2. City; 3. Towers;

(Drawn by Author from the description in F. Bacon's New Atlantis' [2, c.2016-217])

Francis Bacon does not mention the planning or spatial solution of the city, but notes that the city is not very large and is located on the shore of the ocean - has a harbour and ports, and looks picturesque. The streets are described as spacious and light [2, c.198-199]. Probably, there are no fortifications around the city since they don't often have guests from other parts of the world [2, c.198-199]. And those who find themselves in the vicinity of the island cannot go down on it until they prove the goodness of their intentions and confirm that they have not killed or robbed anyone in the last 40 days. An additional requirement is a 3-day quarantine at the Strangers' House. This is quite contradictory to the way T. More and T. Campanella described the fortifications of their cities. For example, the capital city of Utopia - Amaurot is fortified with a wall with bastions and towers, surrounded on three sides by moats and hedges, and on the fourth side by the river $[7$, c. 55].

The lack of a description of residential buildings, and the actual architectural design of public buildings, is explained by Bacon's opinion that buildings are first of all built to live in, not to look on [9]. Perhaps this is why, describing a utopian state, the philosopher pays much more attention to the functional purpose of the buildings, and to the description of the processes that must occur there, rather than to their design and decoration.

Among the public spaces, the author mentioned a harbour and a port [2, c.193]; gardens and vegetable gardens where, besides the cultivation of various plant species, the biology research is also carried out [2, c.218]. There are also wildlife sanctuaries in the country where zoological and ornithological studies are conducted [2, c.218]. All these spaces serve as places where various species of plants, animals, birds and fish can be seen, but, at the same time, experiments are also being carried out there to contribute to the overall development of science on the island.

The Strangers' House is described in great detail - it's a building that was built for the temporary stay of island guests. According to the author's description, it is rather a large building whose function is to shelter people from other countries. Additionally, the building has hospital facilities that are used exclusively by travellers in case of need. The building has a gallery: the glazed gallery is adjacent to the living rooms. The number of rooms that serve as an infirmary is 40 , in addition to these rooms, there are also additional living rooms for guests in the building. The rooms are spacious, beautiful and have a lot of decorations. The building is made of brick with 'of bluer tint than our brick', the inner walls - made of cedarwood [2, c.196]. The windows are partially glazed, partially covered with a linen cloth soaked in oil (Fig. 2).

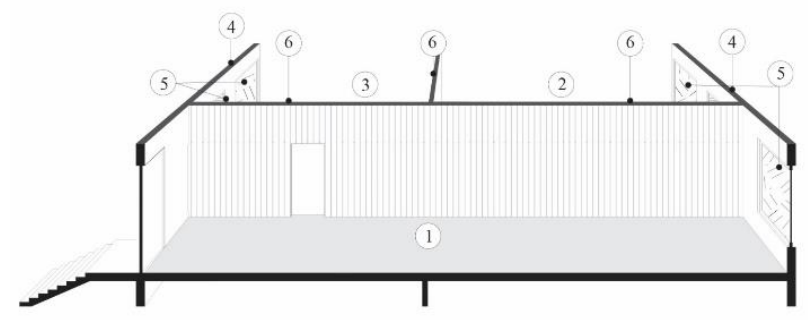

Fig. 2 - House planning perspective view of the Strangers' House 1.Reception hall; 2.Bedrooms; 3.Glazed gallery; 4.Exterior walls (of brick with a blue tint); 5.Windows, part of which is glazed, part tightened with linen cloth; 6.Cedarwood interior partitions (Drawn by Author from the description in F. Bacon's New Atlantis' [2, c.196])

In addition, as science and technology evolve, there are many scientific laboratories in the city where various studies are conducted. For example, there are various workshops where they produce household items, paper, fabrics, paints, and much more [2, c.220]. There is a number of laboratories called 'houses' which are divided by industry. For example, 'perspective-houses' - where scientists study optics [2, c.220]; 'sound-houses' - where scientists explore acoustics [2, c.221]; 'perfume-houses' where scientists experiment on smells and taste reactions [2, c.221]; 'engine-houses' - is a workshop where machines and different movable goods are manufactured [2, c.222]. There are also 'houses of deceit of the senses' where scientists investigate problems and ways of deceiving the sense organs [2, c.222]; 'mathematical houses' the building or a room where various geometric and astronomical instruments are collected [2, c.222]

Among other things, Francis Bacon mentioned confectionery houses, where they make sweets, sweet wines, etc.[2, c.222]; breweries, bakeries, kitchens where various beverages, dishes and all that sort of things are made [2, c.219]; pharmacies [2, c.219].

However, a more detailed description of how buildings should look is presented by Francis Bacon in one of his essays - 'Of Building' (1625). The philosopher pays great attention to the design of buildings, saying that it is impossible to live a healthy life if the house is built in an "unhealthy" place, emphasizing the quality of air, places for sports, etc. Bacon believes that the ideal home should be divided into two parts - one for guests and banquets and the other one for a living. In addition, he believes that 
a courtyard with a fountain is mandatory [9]. All this is described in the essay, but it is not mentioned in his novel 'New Atlantis'. This indicates that in the author's opinion, favourable conditions for research and development of science are of more importance for the existence of a utopian state, than planning the cities and buildings which is, in its turn, minor.

Besides scientific and technical workshops and laboratories, the city has two galleries: the first one presents outstanding inventions - both those that were discovered in other countries and exclusively on the island; the second, - the sculptures of all inventors (not only the local but also the world) [2, c.223-224]. Sculptures are made of copper, marble, jasper, cedarwood or any other wood which is gilded and decorated (gold, silver, iron) [2, c.224]

Among the crafts and applied arts there is also weaving [2, c.214] and carpet making [2, c.215]. F. Bacon pays considerable attention to the description of the various woven fabrics that are used to dress up the inhabitants of the city. Describing the carpets, for example, he writes that they are better than the Persian, thus again emphasizing that everything made by the inhabitants of Bensalem is much better and better than what travellers have ever seen before.

Conclusions. In contrast to previous utopian philosophers, in the novel 'New Atlantis' Francis Bacon shifted the focus from the description of buildings and planning of the city. In his understanding, utopia is not so much about social equality as about scientific and technological progress. Socio-political structure of the island Bensalah is not much different from the government of Great Brit- ain and most European countries of that time. The philosopher describes an iland state which form of government is the monarchy, pointing out that religion (Christianity) plays an important part and thus preserves the notion of family and different social strata. The main institution of the country is Solomon's House, which is a kind of embodiment of the Academy of Sciences. The philosopher paid attention to a large number of research institutions, each of which is responsible for research in various fields ('perspective-houses', 'sound-houses', 'perfume-houses', 'engine-houses' etc.). Describing the structure of the city where travellers are located, Bacon constantly emphasizes that the materials used to build the buildings (the brick with a blue tint which they never saw), the household objects (carpets, which are much prettier than the Persian ones), the mechanisms and scientific discoveries far outstrip those seen by residents of other countries. Pretty scanty description of the architectural and design solutions and the importance of content and features confirm Francis Bacon quote from his essay 'Of Building': 'Houses are built to live in, and not to look on.' [9].

Thus, the utopia described by F. Bacon in the novel "New Atlantis' ' is the first that foremost demonstrates the primacy of science and knowledge, and then later the social and political system of the country. This distinguishes him from the rest of the utopian philosophers and makes his ideas more realistic since the author describes a saentocratic state. For example, for developed countries, it is quite unambiguous to say that science is the most important industry, and in fact allows people to live quality and happy lives, which is the basis of every utopian concept.

\section{REFERENCES}

1. English Oxford Living Dictionaries [online] - Available at: https://en.oxforddictionaries.com/definition/utopia_[Accessed 15 January 2020]

2. Bacon F. New Atlantis/Utopicheskiy roman XVI-XVII vek., 1971//Seriya «Biblioteka vsemirnoy literatury». Seriya pervaya. Sredniye Veka. Vozrozhdeniye. XVII vek. Tom 3, 496 P.

3. Kartunov O. V. Ideyi pryydeshn'oho informatsiynoho suspil'stva ta suspil'stva znan' u tvorchiy spadshchyny Frensisa Bekona//Politychnyy menedzhment, 2007, № 1, P. 48-56

4. Yaldir H., Dilmaçünal A., A City of Science in the Island of New Atlantis (Bensalem); Francis Bacon. Cities in The Globalizing World And Turkey: A Theoretical and Empirical Perspective, 2014, P.623-628
5. Dragomir S., Utopia and New Atlantis, utopia revised. Society and Politics Vol. 5, No. 2(10)/November 2011, P. 32-50

6. Platon, Sobranye Sochynenyi V 4 Tomakh. Tom 4, Moscow, 1994, $830 \mathrm{P}$.

7. More T., Campanella T.,, Utopiia. Misto Sontsia //Vershyny Svitovoho Pysmenstva, Tom 63, Dnipro, 1998, 208 P.

8. Your Dictionary [online] - Available at: https://www.yourdictionary.com/scientocracy - [Accessed 20 January 2020]

9. Bacon F. Of Building.//Essayes: Religious Meditations. Places of Persuasion and Dissuasion. Seene and Allowed. [online] Available https://en.wikisource.org/wiki/The_Works_of_Francis_Bacon ,_Volume_1/Essays/Of_Building - [Accessed 20 January 2020] 